\title{
Towards an Asian Model of Clusters and Cluster Policy: The Super Cluster Strategy
}

- Arkadiusz Michat Kowalski

\begin{abstract}
Clusters are recognized as important drivers of competitiveness and economic development. There are various models of clusters development all over the world, some of which may be initiated bottom-up by private firms, as in most European countries, or top-down by public administrations. In the case of Asian clusters, many are driven by foreign direct investments (FDI), with the most notable example being China. The objective of this study is to examine the Super Cluster strategy introduced in Thailand in 2015, especially in terms of the rationale and mechanism for selecting assisted clusters as well as the instruments used to support them. The goal is to contribute to a more in-depth formulation of the Asian model of clusters and cluster policy. The conducted analysis shows that Thai strategy deviates from traditional bottom-up approaches to cluster policy, veering towards the top-down approach in which government designates targeted regions and industries for the development of clusters. Another finding is that the Super Cluster strategy shares more common characteristics with Special Economic Zones (SEZ) than it does with the traditional approach to cluster policy in terms of its main objective of attracting foreign direct investments (FDI), securing support mechanisms as well as in the selection of target areas and the type of instruments to be implemented. The experience of Thailand is discussed along with that of other Asian countries, most notably China, in order to identify and verify the characteristics of the Asian model of clusters and cluster policy.
\end{abstract}

Keywords: clusters, cluster policy, competitiveness, location quotients (LQ), foreign direct investment (FDI),

Special Economic Zones (SEZ)

JEL Classification: O21, R12, R58

Received: February, 2020

1st Revision: July, 2020

Accepted: September, 2020

\section{INTRODUCTION}

Over the last three decades the concept of clusters has emerged as an important research topic in contemporary economics, both as a business model for the activities of companies and as an economic policy instrument. Following the introduction of the concept of business clusters into economic debates by Porter (1990), it has inspired many researchers and practitioners around the world. Nevertheless, many questions remain unanswered. The economic success of many regional economies which have developed prosperous cluster structures is an incentive for public 
authorities in different parts of the world to formulate strategies towards the implementation of programs which support clustering processes. This concept has also inspired the government of Thailand, which initiated a Super Cluster strategy in 2015. Still, the history of cluster policy in Thailand may be traced back to 2002, when a provincial cluster development policy was launched in the Ninth National Economic and Social Development Plan for 2002-06, the aim of which was to develop clusters in each province as self-contained settlements. The importance of the provincial cluster development policy was also recognized in the Tenth National Economic and Social Development Plan for 2007-11, although no serious policy actions were undertaken at that time. The Eleventh National Economic and Social Development Plan for 2012-16 highlighted the need to support the development of innovative businesses through cluster development by strengthening links and cooperation among businesses along the supply chain.

Together with the increasing popularity of clusters as an economic policy tool, we can observe significant deviations from Porter's original approach, with unique trajectories of clusters and cluster policy development emerging around the world. While the majority of studies examine various clusters and related government actions in developed market economies, mostly in the USA and the European Union, far fewer studies have focused on developing countries. This lack of research remains the case particularly in Southeast Asia, for example, in Thailand. Although cluster policy in emerging markets has been subject to various analyses (Kuchiki \& Tsuji, 2005; Yusuf \& Nabeshima, 2008; Liu, 2015; Gokan et al., 2019), the strategic nature of cluster policies along with associated impacts on economies have been investigated to a much lesser degree than is the case with industrialized countries. The objective of this article is to address this gap by exploring the Super Cluster policy recently introduced in Thailand, especially in terms of the rationale for selecting assisted clusters and the character of instruments used to support them. The research also seeks to contribute to a more in-depth formulation of the Asian model of clusters and cluster policy. The interesting question emerges as to whether the insights acquired through analyzing clustering in industrialized countries still hold true in developing economies.

The relations between SEZ and clusters form another research problem undertaken in this article, as these two structures share similar characteristics, especially in the fact that they both develop within a limited geographic area. Traditionally, clusters have been regarded as restricted to a particular location as well as to closed production systems capable of interacting with external business entities only at the beginning and at the end of the production chain. Meanwhile, progressive globalization processes including the elimination of trade barriers as well as strengthening transport and communication systems have contributed to the intensification of cooperation and the flow of resources at the international level, an effect which is also reflected in cluster activities. Above all, clusters increase a region's investment competitiveness for FDI, which is one of the key motivations of the Super Cluster strategy in Thailand.

Consequently, this article aims to bridge the gap between cluster theory and policy practice by seeking an answer to the key question of whether the Super Cluster strategy recently introduced in Thailand is focused more on enhancing entrepreneurship and business cooperation at the local level or rather on attracting FDI. Further, we seek to explore how these issues are related to the concept of SEZ policy with respect to the objectives of government actions and implemented instruments. 
The structure of the paper is organized as follows. After a literature review, three research questions are formulated in the theoretical background. The next section presents the methods applied in this article. The empirical analysis follows with its focus on the Super Cluster strategy in Thailand examined through the prism of the research questions. The article ends with a conclusions section which summarizes findings from the study and provides insights for further studies in the area of cluster policy in Thailand, and in a broader sense research into the Asian model of clusters.

\section{THEORETICAL BACKGROUND AND RESEARCH QUESTION DEVELOPMENT}

According to the classic definition introduced by Porter (1990), clusters are "geographic concentrations of interconnected companies, suppliers, service providers, firms in related industries, and associated institutions (e.g. universities, standards agencies, and trade associations), in particular, fields that compete but also cooperate." Two key characteristics of clusters may be derived from this definition (Kowalski \& Marcinkowski, 2014):

- geographical and sectoral concentration (regional specialization), i. e. the high representation of companies and other entities operating in a specific sector and related activities in a regional economy

- relationships among cluster actors encompassing both competition and cooperation

It is important to distinguish clusters from cluster initiatives, the latter of which are organized efforts to enhance the competitiveness of a cluster involving private industry, public authorities and/or academic institutions (Sölvell et al., 2003). The increasing popularity of cluster is reflected in the concept of cluster-based economic development policy formulated at the OECD forum (Roelandt \& den Hertog, 1999). Cluster-based economic development is understood as a set of activities and instruments instituted by authorities at various levels to improve economic competitiveness through stimulating the development of existing cluster systems or by creating new systems, primarily at the regional level. As specified in the introduction, different types of practices and models of public intervention are adopted by governments, with the dominant cluster policy models being bottom-up and top-down, or a mix of the two.

Although clusters as initially described by Porter are bottom-up initiatives, governments in transitional or developing countries often adopt the top-down approach (Fromhold-Eisebith \& Eisebith, 2005; Ketels et al., 2006; Skokan et al. 2011; Iritié, 2018). There is a growing gap in analytical rigor between cluster theory studies and programs focusing mostly on bottom-up clusters and cluster policy run by practitioners, who often adopt the top-down approach (Lehmann \& Benner, 2015). The classic approach to clusters is generally in line with the bottom-up approach. Porter (2007) points out that in cluster theory, all clusters are good, thus cluster-based policies, unlike sectoral or industrial policies, should be neutral with regard to the industry or type of economic activity. As sound cluster policy is pro-competition, government should not favor certain clusters, but should support upgrading in every cluster. This view on cluster policy contrasts with the experience of many developing countries, especially in Asia. For example, Okamuro \& 
Nishimura (2015) found out that cluster policy in Asian countries can be regarded as a typical low-incentive policy accompanying an administrative (top-down) selection of targeted clusters with a full funding scheme. This finding was confirmed by Sopoligová \& Pavelková (2017), who claim that cluster policies in Asian countries adopt a top-down approach with the more central role of local government.

Attempts have been made in the literature to describe the Asian model of cluster policy. According to Pessoa (2012), the Asian model combines both a top-down approach and bottom-up approach. However, the origin is always a top-down approach, as the government acts not only as a catalyst and mediator but also as the agent for setting national priorities and devising a challenging vision for the future. The Asian model policy is based on a sequence of actions described by Kuchiki (2008) as the flowchart approach, which stresses the importance of ordering policy measures. This literature review prompts the proposition of the following research question:

Research question 1: What is the nature of the Super Cluster strategy introduced in Thailand? In particular, does it adopt bottom-up or top-down approach?

As stated in the introduction, a specific policy instrument that shares many characteristics with the top-down cluster policy is the creation of SEZ. SEZ are geographically delimited areas which offer benefits for investors, including a separate customs area (duty-free benefits) and streamlined procedures (FIAS, 2008). Although detailed solutions may differ, in particular, countries, the instruments commonly used in SEZ fall into the following groups:

- fiscal incentives; for example: income, property or profit tax exemptions, free or accelerated depreciation, investment tax allowance, a separate customs area providing duty-free benefits,

- non-fiscal incentives, such as: streamlined administrative procedures, exemption from industrial licensing for manufacture of specific products, lax labor laws, subsidies for investment or other costs, free assistance in dealing with formalities connected with the investment, etc.

One of the main characteristics of SEZ and clusters is that both structures develop within a geographically delimited area. However, in the traditional approach to clusters, territorial boundaries are defined in a much more flexible way, since they are usually not subject to administrative decisions. SEZ support the development of industrial clusters which contribute to fostering technology transfer and innovation, which is confirmed by the experience of SEZ in China and Taiwan, which are also success stories of industrial clusters (Hsu et al., 2014). Cluster links with SEZ were also investigated by Farole (2011), who claims that, in the short term, SEZ tend to benefit larger businesses rather than local small and medium enterprises (SME). However, clusterbased policies may be used in the zones to develop stronger links between local enterprises and globally competitive corporations. This integration may lead to unlocking the potential of SEZ as catalysts rather than an enclave of economic development. In respect to the Thai experience, it should be stressed that Super Clusters are developed in the regions designated by government and the instruments used (subject to more detailed analysis in an empirical section of the article) are the fiscal and non-fiscal incentives usually applied in SEZ. In accordance with the Asian model of cluster policy described by Kuchiki (2008), the flow of cluster policy implementation is to establish an industrial zone, to invite an anchor company, and to promote its related 
companies to invest in the industrial zone. This approach is usually accompanied by a precise formalization of incentives and procedures intended to attract FDI and support foreign business (Pessoa, 2012). This literature review leads to the formulation of the following research question: Research question 2: How is the Super Cluster strategy in Thailand related to the concept of SEZ policy with respect to the objectives of government actions and implemented instruments? The process of globalization has influenced clusters and other local production systems to open up their borders, and to increase their linkages with actors outside of their regions. Internationalization is becoming an important dimension of clusters, and it is analyzed in two main perspectives:

1. as clusters' influence on affiliated companies' internationalization behavior (Jankowska \& Götz, 2017),

2. as clusters' influence on increasing location attractiveness of the regions for FDI, and FDI inflows' impact on cluster development (Faria, 2016; Delis \& Kyrkilis, 2017).

From the viewpoint of this article, the second perspective is particularly important, since an analysis of the nature and instruments used in the Super Cluster strategy in Thailand indicates that they are mostly focused on attracting FDI. Giblin \& Ryan (2012) specify that cluster development can be stimulated by foreign investors, and this observation explains policy-makers' attempts to pursue the FDI mechanism for generating regional clusters, although this mechanism works mostly in small countries, such as Ireland. According to Phelps (2008), the results of exogenous public policy to create industrial agglomerations through attracting FDI are still ambiguous, as there is limited research in this field. While numerous studies have investigated the impact of FDI on cluster development and the role of clusters in attracting FDI, far fewer studies have focused on the role of government intervention in these processes. From the perspective of economic policy in Thailand, the impact of clusters in increasing location attractiveness of the regions for FDI seems to be particularly important, as the instruments implemented in the framework of Super Cluster strategy mostly aim to attract FDI. Theoretically, clusters may increase location attractiveness of the regions, influencing the inflow of investments, as geographical proximity offers frequent contacts among actors. Clustering stimulates the inflow of FDI in three ways:

1. indirectly, thanks to cluster features such as closer cooperation, tacit knowledge, low communication costs and other advantages stemming from proximity,

2. directly, since an efficiently functioning cluster can constitute a driving force of regional growth, which is often regarded as the main stimulant for foreign investors to locate their investment in a given location,

3. by government incentives offered in the framework of cluster policy, such as tax subsidies, public subsidies, etc.

The third channel is especially relevant for the analysis conducted in this article, as the Super Cluster strategy offers mainly policy instruments that aim to bring foreign capital to Thailand. There are different studies investigating whether targeted public policy can result in attracting inward foreign investment that can initiate a clustering process. According to the model 
of clusters as a policy tool for attracting FDI presented by Yehoue (2008), the development of economic activity in cluster structures provides public authorities with additional budget income, which enables government to reduce burdens hampering FDI inflow, e.g. in the form of tax exemptions. Phelps (2008) states that clusters emerging in Southeast Asia are at least partly a result of government industrial policies, and they have not been based on localized factors. Hence, the problem for the whole region is relative lack of industrial diversity and the "thinness" of ASEAN's capital asset structure (Bartels, 2004). This was specified by Felker (2004), who states that FDI clustering in Southeast Asia does not correspond to Porter's (1990) competitive "diamond", with a full set of vertical links to supplier and user industries, but is rather a set of horizontal groupings of foreign manufacturers performing similar production functions. The review above leads to the formulation of the third research question:

Research question 3: How important is the international dimension of the Super Cluster policy in Thailand? In particular, is it focused more on enhancing entrepreneurship and business cooperation at the local level or rather attracting FDI?

\section{METHODOLOGY AND DATA}

For the investigation of Super Cluster strategy in Thailand, different research methods were adopted: qualitative, mainly in-depth interviews (IDI) and document analysis, and quantitative, based on statistical analysis of location quotients (LQ). In the first stage, two in-depth interviews (IDI) with representatives of governmental agencies, National STI Policy Office (STI) and the Thailand Board of Investment (BOI) were conducted. They allowed to gather comprehensive information from stakeholders to form a more complete understanding of specificity of the Thai approach to cluster policy and to plan next research steps. It was followed by an analysis of the program websites and Thai government documents regarding the Super Cluster policies, with a focus on the objectives and instruments used in this policy. This research process was carried out using a top-down, deductive approach, starting with theoretical developments giving ground to research questions formulation which are verified through the analysis of collected observations. An analysis of governmental documents allowed for identification of specific Super Clusters selected by the government. However, the top-down cluster policy, in many cases, leads to the selection of clusters that would not be built on local strengths, capabilities, history, and regional specialization. In such case, the selection of a top-down structure may not even satisfy one of the key characteristics derived from Porter's definition of clusters, namely geographical and sectoral concentration. The method applied in this article, which allows to verification of whether the Super Clusters selected by the government of Thailand satisfy the assumption of geographical concentration of related industry, is based on location quotient (LQ). It is a measure developed in regional economics to identify economic structure and specialty, with high values of this measure taken as evidence of a cluster or potential cluster (DTI, 2001). Location quotient, being a ratio rather than an absolute number, makes it possible to contrast the regional level against the national level, thus giving an understanding of a relative sector size. Different studies (Kowalski, 2016) demonstrate the usefulness of this technique in analyzing economic agglomerations. In particular, the methodology applying location quotients (LQ) was used by Resbeut et al. (2019) who investigated the influence of specialization and agglomeration forces on industry perform- 
ance in Thailand. Location quotients are ratios that compare the concentration of a resource or activity in a defined territory to that of a larger, reference area, such as a country, region, or subregion. The formula is as follows:

$L Q_{i}=\left(x_{i} / x\right) /\left(X_{i} / X\right)$

where:

- LQi is the location quotient of industry $\mathrm{i}$ in the local region,

- $\mathrm{x}_{\mathrm{i}}$ is the value of an analyzed indicator (usually employment) of industry $\mathrm{i}$ in a given region,

- $\mathrm{x}$ is the total value of an analyzed indicator in a given region,

- $\mathrm{X}_{\mathrm{i}}$ is a value of an analyzed indicator in industry $\mathrm{i}$ in a reference area,

- $\mathrm{X}$ is a total value of an analyzed indicator in a reference area.

A value of location quotient greater than 1 means that the region has a relatively higher concentration of economic activity in terms of an analyzed indicator in a given industry than the base area. However, in order to identify significantly high geographical concentrations of specific industries, we need to adopt a certain critical value, higher than 1 . It is generally accepted practice to interpret location quotients greater than 1.25 as "high." DTI (2001) calls these industries "high points" of the regional economy. This measurement of the significant overrepresentation of an activity has clear implications for cluster analysis at both theoretical and empirical level, taking into account the main characteristics of cluster structure - geographical concentration and regional specialization.

In this study for Thailand, statistical data for selected regions and industries were obtained from The National Statistical Office (NSO) of Thailand, which conducts the Industrial Census every five years. Statistical data are collected and analyzed according to Thailand Standard Industrial Classification (TSIC 2009), with the following divisions representing selected cluster industries:

(1) Manufacture of motor vehicles, trailers and semi-trailers (Code 29) as the representation of Automotive and Parts Cluster;

(2) Manufacture of electrical equipment (Code 27) as the representation of Electrical Appliances, Electronics and Telecommunication Equipment Cluster;

(3) Manufacture of chemicals and chemical products (Code 20) as the representation of Ecofriendly Petrochemicals and Chemicals;

(4) Motion picture, video and television program production, sound recording and music publishing activities (Code 59), and Computer programming, consultancy and related activities (Code 62) as the representation of Digital-based Cluster.

\section{RESULTS AND DISCUSSION}

A turning point in the cluster policy in Thailand was the strategy introduced in September 2015, aiming to develop two types of clusters: Super Clusters and other targeted clusters. Super Clusters are of particular importance for the economy and the motivation for their development is to increase national investment potentials, production, and international competitiveness, espe- 
cially in terms of trade competitiveness. In the 2015 plan, Super Clusters were established in six sectors using advanced technology and future industries (BOI, 2015):

(1) Automotive and Parts Cluster;

(2) Electrical Appliances, Electronics and Telecommunication Equipment Cluster;

(3) Eco-friendly Petrochemicals and Chemicals;

(4) Digital-based Cluster;

(5) Food Innopolis;

(6) Medical Hub.

In the 2015 strategy, the locations of clusters in the first four of the above-mentioned industries were precisely indicated, leaving the details for Food Innopolis and Medical Hub to be announced at a later stage. On April 11, 2016 the Board of Investment (BOI, 2016) decided to create two additional Super Clusters: Aerospace Industrial Cluster and Automation and Robotics Industrial Cluster (without specifying the targeted location). Four clusters selected in 2015 were located altogether in 9 out of 76 provinces across the country; the analysis in this article focuses on these clusters. The location of clusters selected in four sectors, indicated in the previous section, together with the values of location quotients (LQ) for data on the number of employees, are indicated in Table 1.

Tab. 1 - Location quotients for data on employment in Super Clusters in Thailand. Source: own research

\begin{tabular}{|l|l|l|l|l|}
\hline Region/Cluster & Code 29 & Code 27 & Code 20 & Codes 59 and 62 \\
\hline Nakorn Ratchasrima & 1.07 & 0.15 & & \\
\hline Ayuddhaya & $2.80^{*}$ & $5.31^{*}$ & & \\
\hline Pathum Thani & 0.90 & $4.17^{*}$ & & \\
\hline PrachinBuri & $2.92^{*}$ & $2.53^{*}$ & & \\
\hline Chachoengsao & $5.71^{*}$ & $4.80^{*}$ & & \\
\hline Chon Buri & $4.11^{*}$ & 0.76 & $2.38^{*}$ & \\
\hline Rayong & $4.99^{*}$ & $3.46^{*}$ & $3.52^{*}$ & \\
\hline Chiang Mai & & & & 0.48 \\
\hline Phuket & & & & 0.24 \\
\hline
\end{tabular}

The results of the analysis show that in 12 (out of 18) clusters selected in the first round of the Super Cluster program location quotients are greater than the critical value equal to 1.25 (these values are marked with *), which means they represent strong concentrations of specific industries in designated regions. It may be interpreted that these structures fulfil one of the key theoretical assumptions of Porter's model of clusters, i. e. geographical concentration of economic activity in a particular sector. However, the digital-based clusters in Chiang Mai and Phuket are not reflected in strong employment in motion picture, video and television program production, sound recording and music publishing activities (Code 59), and computer programming, consultancy and related activities (Code 62). Correspondingly, LQ for Automotive and Parts clusters in 
Nakorn Ratchasrima and in Pathum Thani, and Manufacture of Electrical Equipment clusters in Nakorn Ratchasrima and Chon Buri do not reach the threshold of 1.25, which would indicate "high points" of the regional economy. This shows that a top-down policy process may lead to the selection of some structures which, although formally called clusters, do not necessarily represent local strengths, existing assets, and, most importantly, regional specialization.

It is also important to investigate the links between the policies for clusters and SEZ in Thailand. The second research question is about the character of the Super Cluster strategy, especially its relation to the concept of SEZ policy, with respect to the objectives of government actions and implemented instruments. Searching for the answer to this question requires analysis of the nature of the Super Cluster policy in Thailand and the instruments used. First of all, it is remarkable that it is the Thailand Board of Investment that is the public entity responsible for Super Cluster strategy. BOI is the principal government agency for encouraging foreign investments, and providing different types of business support services and advice on establishing operations in Thailand. Correspondingly, the instruments for Super Clusters include:

- 8-year corporate income tax exemption,

- additional 5-year 50\% reduction in the normal rate of corporate income tax on the net profit deriving from the promoted activity,

- import duty exemption on machinery, and on raw materials and components for re-export products;

- consideration of granting permanent residence to the leading specialist,

- permission for foreigners to own land to implement the promoted activities.

In addition, the Thai government has also approved a 269 million USD fund, which would include matching grants to encourage and support investors in the high value-added activities in the Super Cluster, such as R\&D activities and training. In order to qualify for the abovementioned instruments, companies submit applications, which are then considered by BOI on the basis of the following approval criteria:

- activity should be classified under eligible BOI categories,

- activity should be located in the designated provinces for each relevant cluster,

- applicant should cooperate with academic institutions, research institutions or centers of excellence in the designated areas.

The investigation into the nature of the Super Cluster policy in Thailand requires the analysis of it through the prism of three economic policy approaches, as presented in Table 2. One of them is the SEZ policy, the other two belong to the category of cluster policy. However, as described earlier, there are different variations of cluster policy, with two key approaches: bottom-up (market driven, with the secondary role of government, which intervenes only if there is market failure), and top-down (with a dominant role of the government).

The analysis presented in Table 2 shows that the tools proposed in the framework of the Super Cluster plan in Thailand share all characteristics with the mechanisms usually applied in the SEZ policy, both in terms of how supported areas are designated, and which types of fiscal 
and non-fiscal instruments are used. However, they share no common features with the classic, bottom-up approach to cluster policy. Finally, the Super Cluster strategy shares one important common characteristic with a government-driven, top-down approach to cluster policy, which is a deviation from the classic M.E. Porter cluster theory. This shared element is the mechanism of designating specific regions for public support through government decision.

Tab. 2 - Correspondence of instruments used in the Super Cluster policy in Thailand with different economic policy approaches. Source: own research

\begin{tabular}{|c|c|c|c|}
\hline \multirow{3}{*}{$\begin{array}{l}\text { Instruments used in the Su- } \\
\text { per Cluster policy in Thai- } \\
\text { land }\end{array}$} & \multicolumn{3}{|c|}{ Consistency of the instrument with traditional understanding of: } \\
\hline & \multicolumn{2}{|c|}{ Cluster policy } & \multirow[b]{2}{*}{ SEZ policy } \\
\hline & $\begin{array}{l}\text { Market-driven, bot- } \\
\text { tom-up approach }\end{array}$ & $\begin{array}{l}\text { Government-driven, top- } \\
\text { down approach }\end{array}$ & \\
\hline $\begin{array}{l}\text { Mechanism of designating } \\
\text { specific territories for inter- } \\
\text { vention by government }\end{array}$ & $\begin{array}{l}\text { ( -)Not existing, } \\
\text { potentially compe- } \\
\text { titive clusters are } \\
\text { supported wherever } \\
\text { they emerge }\end{array}$ & $\begin{array}{l}(+) \text { Government usually in- } \\
\text { dicates the specific territories } \\
\text { to develop clusters, but not } \\
\text { necessarily with precisely de- } \\
\text { fined boundaries }\end{array}$ & $\begin{array}{l}(+) \text { Government pre- } \\
\text { cisely designates spe- } \\
\text { cific territories with } \\
\text { distinct regulations }\end{array}$ \\
\hline $\begin{array}{l}\text { Fiscal } \\
8 \text {-year corporate income } \\
\text { tax exemption } \\
\text { additional } 5 \text {-year } 50 \% \text { re- } \\
\text { duction on the normal rate } \\
\text { of corporate income tax on } \\
\text { the net profit deriving from } \\
\text { the promoted activity } \\
\text { import duty exemption on } \\
\text { machinery, and on raw ma- } \\
\text { terials and components for } \\
\text { re-export products }\end{array}$ & \multicolumn{2}{|c|}{$\begin{array}{l}\text { (-)In principle, clusters operate in the same fiscal } \\
\text { environment as all other entities in the economy. } \\
\text { Clusters may receive different types of public sup- } \\
\text { port, like subsidies for partial financing of cluster } \\
\text { governance structures or theme-based collective ac- } \\
\text { tions, but specific fiscal incentives are rarely applied } \\
\text { (however, there may be occasional exceptions, e.g. } \\
\text { tax incentives for R\&D activities). }\end{array}$} & $\begin{array}{l}(+) \text { Fiscal incentives } \\
\text { such as tax exemp- } \\
\text { tions or import du- } \\
\text { ties are typical instru- } \\
\text { ments of SEZ policy }\end{array}$ \\
\hline $\begin{array}{l}\text { Non-fiscal } \\
\text { consideration of granting } \\
\text { permanent residence to the } \\
\text { leading specialist } \\
\text { permission for foreigners } \\
\text { to own land to implement } \\
\text { the promoted activities }\end{array}$ & \multicolumn{2}{|c|}{$\begin{array}{l}\text { (-) Special administrative rules for foreign wor- } \\
\text { kers or legal entities are usually not applied. The- } \\
\text { re may be soft actions undertaken by (semi)govern- } \\
\text { ment in order to increase investment attractiveness } \\
\text { of the cluster, like market information for internati- } \\
\text { onal purposes, providing assistance in partner sear- } \\
\text { ches or supply-chain linkage support }\end{array}$} & $\begin{array}{l}(+) \text { Non-fiscal incen- } \\
\text { tives in the form of } \\
\text { lax labor laws or stre- } \\
\text { amlined procedu- } \\
\text { res for foreign inves- } \\
\text { tors are often applied } \\
\text { in SEZ }\end{array}$ \\
\hline
\end{tabular}

Note: $(+)$ : corresponding; $(-)$ : not corresponding

What is characteristic in the Super Cluster policy in Thailand is the fact that financial support is granted to individual companies which submit applications. This approach differs from the instruments used in Europe and the United States, where public support is usually directed through cluster organizations to encourage different types of collaborative actions between cluster members (like undertaking common Research and Development projects), or to benefit the whole cluster (e. g. promotional and marketing activities, the collection and processing of knowledge and information in the areas of interest to the cluster, creating specialized research, transportation, communications and other infrastructure defining a cluster's profile, or developing special training programs for cluster employees). As for the Super Clusters in Thailand, the 
only approval criteria for receiving public support connected with cooperation at the local level is to have cooperation with academic institutions, research organizations or centers of excellence in the designated areas. Apart from that, assisted companies appear to act in isolation, and no coordinating structures in the form of cluster initiatives are required. This is another characteristic which brings the Super Clusters in Thailand closer to the SEZ idea rather than to the cluster policy concept.

The development of SEZ initiated in 2014 is another type of economic policy in Thailand. By the end of 2016, the government had set up 13 zones in 10 provinces around its national borders, both inside and outside of industrial estates. In fact, opening SEZ in Thailand is one of several factors contributing to the decentralization of national economic development away from Bangkok, especially to the border regions. An important motive for this location of SEZ is also to create economic connectivity with neighboring countries and to integrate with the ASEAN Economic Community (AEC). Businesses located in SEZ are granted different privileges, mainly (BOI, 2014):

- corporate income tax exemptions for up to 8 years and, for some selected activities, an additional $50 \%$ corporate income tax exemption for 5 years,

- 10-year permission to double deduct costs of transportation, electricity and water supply, and to deduct $25 \%$ of investment costs on the installation or construction of facilities used, counting from the date in which revenue is generated,

- exemption from import duty for machinery, and for raw materials and essentials used in production for export for a period of 5 years,

- non-tax incentives, such as permission to employ foreign unskilled workers in the promoted project.

The incentives listed above are very similar to the instrument used for Super Clusters, which also provides an answer to the second research question demonstrating that the Super Cluster strategy in Thailand shares more common characteristics with the SEZ policy than with the traditionally understood role of government in supporting clusters.

Moreover, it is important to note that Super Clusters are generally selected in modern industries with high value added, enhancing strategic location advantages and improving the investment environment in Thailand. The flow of capital, technology, and human resources promotes more vibrant economic activities at the local level, thereby stimulating inclusive economic growth. As targeted investment promotion measures generally focus on the high-tech sector with a high growth potential, FDI could raise the overall competitiveness of the Thai economy through technology transfer (Tulayasathien \& Tejapaibul 2017).

It should be stressed that the crucial role of FDI is a common characteristic of clusters in many Asian countries. For example, we observe the dynamic emergence of clusters in China, especially centered in special economic zones (Zeng, 2012) with a strong role of multinational corporations investing in Chinese regions where related industries are highly clustered (Fri et al., 2013). In fact, although megacities like Beijing and Shanghai have long captured much of the spotlight as potential investment destinations, the real economic miracle of China has occurred behind the 
scenes in second-tier cities such as Chongqing, Wuhan, Ningbo and Dalian, which have become important locations for innovative clusters (Kowalski 2019). Foreign investments constitute one of the most notable channels of international technology transfer to China, which has resulted in technological spill overs into various Chinese regions, especially those in which FDI inflow is spatially more concentrated (Cheung \& Lin, 2004). This shows the importance of emerging high-technology clusters. Clusters are also an important element of innovation systems of other Asian innovation leaders, such as is the case with South Korea. Hong et al. (2012) found that the Korean electronics industry has successfully caught up with first movers such as the Japanese and US electronics industries thanks to industrial clusters which have encouraged innovation through collaborations with foreign firms as well as with other industries to establish such a rapid catch-up.

\section{CONCLUSION}

This paper discusses the topic of clusters and cluster policy with a focus on the latest developments in the Super Cluster strategy in Thailand. The emergence of clusters all over the world shows that, although this concept was originally associated mostly with the experience of mature market economies, it is a universal model which may be applied to analyze regional industrial structures in all types of countries, regardless of the level of development or economic policy regime. As presented in the article, various approaches to determining economic policy within the process of initiating and developing clusters have been attempted. The experience of different countries, especially in Asia, demonstrate the variations of cluster policy, some of which significantly deviate from the original approach presented by Porter. With respect to research question 1 , the analysis conducted in this study shows that Thailand's Super Cluster strategy diverges from the traditional bottom-up approach to the role of government in supporting clustering processes. In geographical terms, the assisted areas were carefully selected by public authorities, which is in line with the top-down approach to cluster policy. However, the statistical analysis of location quotients (LQ) shows that most of the Super Clusters were selected in accordance with the regional specialization of the respective territory. This shows that the top-down cluster policy may also lead to satisfactory results with respect to building on the strengths of regional economies. Nevertheless, some Super Clusters designated by the government do not represent the geographical concentration of a specific industry, a finding which fails to satisfy one of the key assumptions of the original cluster model. This shows that in adopting the top-down approach to cluster policy, the location of the assisted clusters must be decided upon very carefully, taking into account local strengths, assets and, above all, the pattern of regional specialization. It must be emphasized that the conclusions of this paper are not intended to recommend which model of cluster policy should be favored, since there is no one-size-fits-all approach. This finding is consistent with those of many researchers, such as Asheim et al. (2017) and Sopoligová \& Pavelková (2017).

Another finding of the article is related to the problem of the organizational structure of clusters. It is worth noting that a cluster organization acting as a coordinating body is not necessary for a cluster initiative be eligible for public funding in the framework of the Super Cluster policy in Thailand. Interestingly, this organizational pattern with "clusters without cluster initiatives" 
which also occurs in other countries in Asia, and therefore may be referred to in terms of the Asian model, is the opposite of the problem that occurs in European countries (Kowalski \& Marcinkowski, 2014), in which many artificial cluster initiatives emerge as a result of entrepreneurial efforts to apply for public support, but which do not represent real clusters as understood as actual market structures with strong regional specialization. The Thai model of "non-institutionalized" Super Clusters may hinder the potential influence on the clusters on economic performance according to Delgado et al. (2014). Qualitative studies of clusters such as this one have highlighted the important role of specialized local institutions such as training facilities and infrastructure investment initiatives in the exploitation of potential complementarities.

With respect to research question 2, it was found in this article that the list of instruments used in support of Super Clusters is very similar to standard fiscal and non-fiscal incentives usually implemented in SEZ. Nevertheless, this result is significantly different from results indicated in Porter's classic description of cluster policy tools. Taking into account both aims and instruments of this strategy, the Super Cluster policy in Thailand is rather a variation of the SEZ policy than a traditional approach to the governmental role in supporting clusters. Generally, one of the key objectives of SEZ is to attract FDI, which is also the main ambition of the Super Cluster policy in Thailand. This provides an answer to research question 3, i. e. the strong international dimension of the Super Cluster policy in Thailand is focused more on attracting FDI than on enhancing entrepreneurship and business cooperation at the local level. This shows the differences in clustering processes between developed and middle-income countries. In Europe or the USA a much stronger role is played by local enterprises, with clusters built more on local assets, strengths, and existing social capital. In developing economies such as those of Southeast Asia emphasis has been placed more on attracting FDI with all its related benefits, including financial capital inflow, job creation, increasing the level of domestic competition, technology transfer, etc. As shown by Tvaronavičienè \& Razminienè (2017), this is especially important for low and middle-income countries, in which the access to foreign markets, attracting foreign investments, and global knowledge networks are essential ingredients to the growth and development prospects.

The study seeks to contribute to cluster theory, in particular to the formulation of the Asian model of clusters and cluster policy. The Asian model differs in many ways in terms of the practices observed in developed market economies such as the European Union and the USA. The following differing elements can be indicated:

- the strong role of FDI which take the central place in the cluster structure

- a weaker focus on local companies, especially small and medium enterprises (SME)

- a less developed local system of relationships and a weaker cooperation among cluster actors

- the strong role of government, which adopts a top-down approach to cluster policy

- cluster policy tools directed mainly at attracting FDI, such as tax exemptions or streamlined procedures for foreign investors, which are similar to the instruments traditionally used in SEZ

- the weaker role of soft policy measures, for example, those aiming at human and social capital formation in the regional economy 
- a less developed institutional sphere in the form of a formalized cluster initiative, and the lack of s cluster organization that would coordinate common actions and usually be a direct beneficiary of public support (e.g. in EU member states)

This study can provide a number of recommendations which may be taken into account in economic policy in developing countries such as Southeast Asia and especially Thailand. For middle-income economies, supporting clusters may be a good strategy for economic development, allowing the attraction of foreign capital on the one hand, and boosting local industrial activity around foreign investments on the other. However, greater attention should be devoted toward policies to create preconditions in specific regions for developing a local business base that would stimulate endogenous development processes in addition to FDI-led growth. By enhancing local links among enterprises and interregional connections, emerging clusters may develop into growth poles for the regional as well as national economy.

Several directions for future research can be suggested which may increase knowledge on clusters and cluster policy. In particular, the specificity of cluster development in middle-income countries would be a primary focus which could also contribute to a more complete formulation of the Asian model of clusters.

\section{Acknowledgments}

This work was supported by the National Science Center, Poland, under Grant No. 2016/21/B/ HS4/03025.

\section{References}

1. Asheim, B. T., Isaksen, A., Martin, R., \& Trippl, M. (2017). The role of clusters and public policy in new regional economic path development. D. Fornahl \& R. Hassink (Eds), The life cycle of clusters: A policy perspective. Cheltenham: Edward Elgar Publishing.

2. Bartels, F. (2004). The future of intra-regional foreign direct investment patterns in Southeast Asia. N. Freeman \& F. Bartels (Eds), The Future of Foreign Investment in Southeast Asia, 80-103. London: Routledge.

3. Bialic-Davendra, M. L. (2011). An investigation of a new concept of world class clusters in Europe a case study of the Visegrad Group of Countries. Journal of Competitiveness, 2, 43-57.

4. BOI. (2014). Announcement of the Board of Investment No. 4/2557. Investment Promotion in Special Economic Development Zones. Announced on the 18th of December 2014.

5. BOI. (2015). Announcement of the Board of Investment No. 10/2558. Cluster investment promotion incentives and privileges in the Special Economic Development Zones. Announced on the 27th of October 2015.

6. BOI. (2016). Announcement of the Board of Investment No. 7/2559. Additional Amendments of Eligible Activities for Investment Promotion in accordance with Cluster Investment Promotion Incentives and Privileges in the Special Economic Development Zones. Announced on the 11th of April 2016.

7. Cheung K. Y., \& Lin P. (2004). Spillover effects of FDI on innovation in China: evidence from the provincial data. China Economic Review, 15 (1), 25-44.

https://doi.org/10.1016/S1043-951X(03)00027-0 
8. Delgado, M., Porter, M. E., \& Stern, S. (2014). Clusters, convergence, and economic performance. Research Policy, 43 (10), 1785-1799. http://dx.doi.org/10.1016/j.respol.2014.05.007

9. Delis, T., \& Kyrkilis, D. (2017). Locational Concentration of Foreign Direct Investment in China: a Cluster Factor-Based Analysis. Journal of the Knowledge Economy, 8 (4), 1115-1132. http://dx.doi.org/10.1007/s13132-016-0367-7

10. DTI (2001). Business clusters in the UK - a first assessment, London: Department of Trade and Industry.

11. Faria, J. R. (2016). Location clusters, FDI and local entrepreneurs: consistent public policy. Journal of the Knowledge Economy, 7 (4), 858-868. http://dx.doi.org/10.1007/s13132-015-0272-5

12. Farole, T. (2011). Special Economic Zones in Africa: Comparing performance and learning from global experience. Washington D. C.: World Bank. http://dx.doi.org/10.1596/978-0-8213-8638-5

13. Felker, G. B. (2004). Global production and Southeast Asia's industrialization. K. Jayasuriya (Ed.), Asian Regional Governance: Crisis and Change, 82-105. London: Routledge.

14. FIAS. (2008). Special Economic Zones. Performance, Lessons Learned, and Implications for Zone Development. Foreign Investment Advisory Service (FIAS), World Bank, Washington, D. C.

15. Fri, W., Pehrsson, T., \& Søilen, K. S. (2013). How Phases of Cluster Development are Associated with Innovation - the Case of China. International Journal of Innovation Science, 5 (1), 31-44. https://doi.org/10.1260/1757-2223.5.1.31

16. Fromhold-Eisebith, M., \& Eisebith, G. (2005). How to institutionalize innovative clusters? Comparing explicit top-down and implicit bottom-up approaches. Research policy, 34 (8), 1250-1268. http://dx.doi.org/10.1016/j.respol.2005.02.008

17. Giblin, M. \& Ryan, P. (2012). Tight clusters or loose networks? The critical role of inward foreign direct investment in cluster creation. Regional Studies, 46 (2), 245-258. http://dx.doi.org/10.1080/00343404.2010.497137

18. Gokan, T., Kuroiwa, I., Laksanapanyakul, N. \& Ueki, Y. (2019). Spatial structures of manufacturing clusters in Thailand, Cambodia and Lao People's Democratic Republic. Journal of the Asia Pacific Economy, 25 (3), 1-29. http://dx.doi.org/10.1080/13547860.2019.1665307

19. Hong, P., Amano, T., \& Moon, G. (2012). Benchmarking open and cluster innovation: case of Korea. Benchmarking: An International Journal, 19 (4/5), 517-531. http://dx.doi.org/10.1108/14635771211257981

20. Hsu, M. S., Lai, Y. L., \& Lin, F. J. (2014). The impact of industrial clusters on human resource and firms performance. Journal of Modelling in Management, 9 (2), 141-159. http://dx.doi.org/10.1108/JM2-11-2012-0038

21. Iritié, B. J. J. (2018). Economic issues of innovation clusters-based industrial policy: a critical overview. Global Business and Economics Review, 20 (3), 286-307. http://dx.doi.org/10.1504/GBER.2018.091707

22. Jankowska, B., \& Götz, M. (2017). Internationalization intensity of clusters and their impact on firm internationalization: the case of Poland. European Planning Studies, 25 (6), 958-977. http://dx.doi.org/10.1080/09654313.2017.1296111 
23. Ketels, C. (2013). Cluster policy: A guide to the state of the debate. In: P. Meusburger, J. Glückler \& M. el Meskioui (Eds), Knowledge and the Economy, 249-269. Dordrecht (Netherlands): Springer. http://dx.doi.org/10.1007/978-94-007-6131-5_13

24. Ketels, C., Lindqvist, G., \& Sölvell, Ö. (2006). Cluster Initiatives in Developing and Transition Economies. Stockholm: Center for Strategy and Competitiveness.

25. Kowalski, A. M. (2016). Territorial location of ICT cluster initiatives and ICT-related sectors in Poland. Drewello, M., Bouzar, M., \& Helfer (Eds), Clusters as a Driving Power of the European Economy, 4-66. Baden-Baden: Nomos.

26. Kowalski, A. M., \& Marcinkowski, A. (2014). Clusters versus cluster initiatives, with focus on ICT sector in Poland. European Planning Studies, 22 (1), 20-45. http://dx.doi.org/10.1080/09654313.2012.731040

27. Kowalski A. M. (2019). The perspectives on interregional cluster cooperation under BRI Frame. Shi J., \& Heiduk G. (Eds). Opportunities and Challenges. Sustainability of China-EU Relations in a Changing World, China Social Sciences Press, Beijing, 189-209.

28. Kuchiki, A. (2008). Appendix: Theory of a Flowchart Approach to Industrial Cluster Policy. A. Kuchiki \& M. Tsuji (Eds), The Flowchart Approach to Industrial Cluster Policy, 285-313. Basingstoke: Palgrave Macmillan.

29. Kuchiki, A., \& Tsuji, M. (2005). Industrial clusters in Asia: analyses of their Competition and Cooperation. Basingstoke: Palgrave Macmillan.

30. Lehmann, T., \& Benner, M. (2015). Cluster Policy in the Light of Institutional Context - A Comparative Study of Transition Countries. Administrative Sciences, 5 (4), 188-212. http://dx.doi.org/10.3390/admsci5040188

31. Liu, M. C. (2015). Manufacturing servitization and revitalizing industrial clusters: a case study of Taiwan's LIIEP. Journal of the Asia Pacific Economy, 20 (3), 423-443. http://dx.doi.org/10.1080/13547860.2015.1054168

32. Lucena-Piquero, D. \& Vicente, J. (2019). The visible hand of cluster policy makers: An analysis of Aerospace Valley (2006-2015) using a place-based network methodology. Research Policy, 48 (3), 830-842. http://dx.doi.org/10.1016/j.respol.2019.01.001

33. Okamuro, H., \& Nishimura, J. (2015). Local management of national cluster policies: Comparative case studies of Japanese, German, and French biotechnology clusters. Administrative Sciences, 5 (4), 213-239. http://dx.doi.org/10.3390/admsci5040213

34. Pessoa, A. (2012). Regional cluster policy: The Asian model vs, the OECD approach. MPRA Paper No 42024, Munich Personal RePEc Archive.

35. Phelps, N. A. (2008). Cluster or capture? Manufacturing foreign direct investment, external economies and agglomeration. Regional Studies, 42 (4), 457-473. http://dx.doi.org/10.1080/00343400701543256

36. Porter, M. E. (1990). The Competitive Advantage of Nations. New York: Free Press. http://dx.doi.org/10.1007/978-1-349-11336-1

37. Porter, M. E. (2000). Location, competition, and economic development: Local clusters in a global economy. Economic Development Quarterly, 14 (1), 15-34.

http://dx.doi.org/10.1177/089124240001400105 
38. Porter, M. E. (2007). Clusters and Economic Policy: Aligning Public Policy with the New Economics of Competition, White Paper, Institute for Strategy and Competitiveness, Harvard Business School.

39. Resbeut, M., Gugler, P., \& Charoen, D. (2019). Spatial agglomeration and specialization in emerging markets: economic efficiency of clusters in Thai industries. Competitiveness Review: An International Business Journal, 29 (3), 236-252. http://dx.doi.org/10.1108/CR-10-2018-0065

40. Roelandt, T. J. A., \& den Hertog, P. (1999). Cluster Analysis and Cluster-based Policy Making: The State of the Art. Boosting innovation: The cluster approach, 413-427. Paris: Organisation for Economic Co-operation and Development.

41. Skokan, K., Poledníková, E., \& Stanícková, M. (2012). Establishment and growth of business clusters with public aid. Journal of Competitiveness, 4 (3), 14-28.

http://dx.doi.org/10.7441/joc.2012.03.02

42. Sölvell, Ö., Lindqvist, G., \& Ketels, C. (2003). The Cluster Initiative Greenbook. Stockholm: Ivory Tower AB.

43. Sopoligová, M., \& Pavelková, D. (2017). Cluster policy in Europe and Asia: A comparison using selected cluster policy characteristics. Journal of International Studies, 10 (3), 35-50. http://dx.doi.org/10.14254/2071-8330.2017/10-3/3

44. Tulayasathien, S., \& Tejapaibul, A. (2017). Investment Promotion and Liberalization in Selected ASEAN Countries. Thirawat, N. (Ed.). Internationalization and Managing Networks in the Asia Pacific, 29-51. Chandos Publishing.

45. Tvaronavičienè, M., \& Razminienè, K. (2017). Towards competitive regional development through clusters: approaches to their performance evaluation. Journal of Competitiveness, 9 (4), 133-147. https://doi.org/10.7441/joc.2017.04.09

46. Yehoue, E. B. (2009). Clusters as a driving engine for FDI. Economic Modelling, 26 (5), 934-945. http://dx.doi.org/10.1016/j.econmod.2009.03.006

47. Yusuf, S. \& Nabeshima, K. (2008). Growing industrial clusters in Asia: serendipity and science. Washington D.nC.: World Bank. http://dx.doi.org/10.1596/978-0-8213-7213-5

48. Zeng, D. Z. (2012). China's special economic zones and industrial clusters: the engines for growth. Journal of International Commerce, Economics and Policy, 3 (03), 1-28.

http://dx.doi.org/10.1142/S1793993312500160

\section{Contact information}

prof. Arkadiusz Michat Kowalski, Ph.D.

SGH Warsaw School of Economics

Collegium of World Economy

World Economy Research Institute

Department of East Asian Economic Studies

Poland

E-mail: arkadiusz:kowalski@sgh.waw.pl

ORCID: 0000-0002-0857-352X 